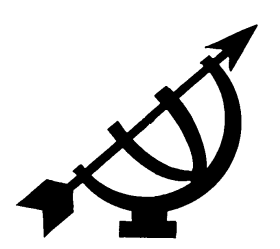

\title{
The need to understand the emotions of anger, fear and guilt when counselling religious cult victims
}

\author{
S.P. Pretorius \\ Registration Administration \\ Unisa \\ PRETORIA \\ Email: pretosp@unisa.ac.za
}

\begin{abstract}
The need to understand the emotions of anger, fear and guilt when counselling religious cult victims

Victims of religious cults are systematically influenced by the beliefs, teachings and practices of the group to adopt the identity and personality befitting the religious cult. This cult identity and personality that is believed to be God-pleasing views the outside world as evil and a threat to the spiritual well-being of cult members. In order to maintain cult members in a state which is supposedly pure and free from contamination by the evil world, they are taught to cultivate an antagonistic and resistant attitude towards any doctrine or person contradicting the cult's views. Any attempt by an "outsider" to communicate with cult members is prohibited. Any attempt to counsel cult members must be preceded by the establishment of a trust relationship that will overcome the resistance and open up communication. The counselling process that follows should address the emotional conditions of anger, false guilt and fear in order to restore the person's self-worth and ability to adapt to the outside world. This article contends that addressing false guilt, anger and fear is an important and necessary phase in the process of helping cult members to recover and reintroducing them to the world.
\end{abstract}




\section{Opsomming}

\section{Die noodsaaklikheid om emosies van woede, vrees en skuldgevoel tydens berading van slagoffers van godsdienstige kultes te verstaan}

Slagoffers van godsdienstige kultes word stelselmatig deur die oortuigings, leerstellings en praktyke van die groep beïnvloed ten einde die identiteit wat deur die groep voorgeskryf word, aan te neem. Daar word geglo dat die nuwe identiteit en persoonlikheid wat die kulte voorskryf vir God aanvaarbaar is en dat kontak met die "bose" buitewêreld vermy moet word, omdat dit nadelig vir die geestelike welstand van die kultelede is. Ten einde rein en vry van besoedeling te bly, word kultelede subtiel beïnvloed om 'n vyandige houding teenoor enige leerstellings strydig met dié van die groep in te neem. Kommunikasie met "buitestanders" word sover moontlik verbied. Ten einde berading aan kultelede moontlik te maak, is die vestiging van 'n vertrouensverhouding noodsaaklik omdat dit hierdie weerstand sal oorkom en kommunikasie moontlik sal maak. Die beradingsproses wat volg moet die emosies van 'n valse skuldgevoel, woede en vrees hanteer ten einde die kultelid se selfbeeld te herstel, asook die vermoë om weer in die gemeenskap aan te pas. Hierdie artikel voer aan dat die hantering van 'n valse skuldgevoel, woede en vrees 'n belangrike en noodsaaklike fase is in die proses om kultelede terug te wen en weer deel van die samelewing te maak.

\section{Introduction}

Repeated adherence to the rules, instructions and rituals of the cult and respect for the older cult members are the tools used to initiate members of religious cults into the cult world. Total commitment to the prescriptions of the cult systematically enforces behavioural change that is best achieved in an isolated environment which alienates and separates members from the outside world.

The dynamics of religious cults subtly dictate to members an all-ornothing attitude. The cult is presented as the only means of obtaining true salvation. The process of proselytising new members normally commences with an appealing emotional experience (or experiences) known as "love bombing" that gives the perception of real interest in the well-being of the person. The affectionate attention relaxes and makes the person more susceptible to the new ideas of the cult (Singer \& Lalich, 1995:114). This opportunity is utilised to point out the defects in the potential member's value system, worldview, view of God, educational, religious and political 
structures in order to create doubt in the person's own mind. Doubt about the person's current world creates a need for change and a possible solution. The change and solution are presented in the lifestyle of the cult. The degree of commitment to the cult is normally demonstrated by confessing to the insufficiencies of the person's own world, followed by a radical break with this world and lifestyle.

To facilitate new members' adaptation to the new cultic world, their own worldview, frame of reference, belief system and identification structures are replaced by the cult's culture, doctrines, prescriptions and belief system. A redefining of the "self" occurs. Members are also kept to the prescriptions of the group by means of continuous reprimanding and punishment if rules are broken. Punishment includes being ignored, shunned or overlooked, or aggressive legalism such as being questioned, openly censured or asked to leave the group (Johnson \& VanVonderen, 1991:67-68). They realise that the best way to overcome their own inability, stay on track and please God is to surrender totally to the instructions and guidance of the leader. Slowly but surely the member's own personality and identity are replaced by a personality and identity prescribed by the cult. Then the controlled environment and submission to the instructions of the cult systematically numb the ambitions, critical thinking faculties and personal viewpoints of members. Also, the fear that the one that leaves the group will encounter divine judgement complicates the exit process (Zukeran, 2006:4). Members thus become physically, emotionally and spiritually dependent on the instructions and directions of the cult. In fact, members mechanically act out the ideal cult identity and personality. A person has been made receptive to new ideas because their critical faculties and ego strength have been eroded by techniques such as information control, overstimulation of the nervous system, forced confessions and ego destruction (Snow \& Machalek, 1984:178).

The cult's identity is maintained through emotions of fear, guilt and love. When members leave the cult after a period of time, they are fearful and insecure about making their own decisions, utilising their critical thinking faculties and evaluating circumstances on their own in the outside world.

The behavioural change established by the cult is so deep-rooted that it causes members who leave to experience a sense of disorientation, anger, false guilt and fear, which prohibits them from adapting to the outside world. 
The aim of this article is first of all, to explain the impact of these emotions on cult members; secondly, to demonstrate how to deal with these emotional conditions in order to start the healing process; and finally, to reintroduce ex-cult members to the world they have been alienated from. The physical, spiritual and emotional state of the cult member will be discussed first.

\section{Spiritual, emotional and physical condition of the cult member}

Cult members leave cults after realising that the cult is not what it purported to be and that they have actually been misled. This realisation triggers an internal spiritual tension challenging members to choose either to leave the group they believe is turning its back on God, or to remain in the group. This is no easy decision, as they know that they have broken ties with their support system in the world outside the group. When members eventually succeed in leaving the cult, they enter the "evil" outside world as lonely people with serious spiritual, emotional and even physical damage.

Spiritually, members normally experience the fear of losing their salvation because they have left the group and in so doing turned their back on God. They also develop a distorted image of God and a distorted self-image of themselves as Christians. Some may have difficulty with the concept of grace. Most members become distrustful of any kind of authority, especially religious leadership.

The following emotional conditions are also recorded: major depression with suicidal tendencies and depression resulting from the collapse of the entire belief system they had wholeheartedly committed to. Another symptom is anger towards the responsible leaders. A sense of purposelessness and alienation from reality coupled with an unbearable loneliness, isolation and alienation, ensues. Members experience the feeling that nobody understands their specific situation and they fear that they will go mad. This feeling causes the battered follower to withdraw. Embarrassment at having been susceptible enough to be abused and even to participate in recruiting other followers is common. Some members have repeated nightmares and others experience dissociation. Families of the victims are heartbroken and in many cases the relationships are destroyed. Parents tend to neglect their children as a result of their total commitment to the group (Damiani, 2002:45-46; Henke, 2006:3-4; Johnson \& VanVonderen, 1991:41-50 and Langone, 1993:238-239). 
Physical and material conditions include cult members giving up careers and possessions and thus facing frustration as well as dismal career paths and financial futures. The leader traps some victims in arranged marriages. Others may be sexually abused.

When considering reintroducing a cult member to society, all the possible spiritual, emotional and physical factors must be taken into account. For the purpose of this article the focus will be on the emotional conditions of anger, false guilt and fear and the need to understand these.

\section{Dealing with the emotional conditions of cult members}

Emotions typically occur when individuals perceive significant positive or negative changes in their personal situation or in the situations of those related to them. Emotions serve to monitor and safeguard a person's personal concerns and to give the eliciting event its significance (Ben-Ze'ev, 2000:13, 17).

\subsection{Anger}

Although theorists disagree about whether anger is a primary human emotion or a more general distress state, they do agree that anger serves a variety of adaptive functions. Anger organises and regulates internal physiological and psychological processes relating to self-defence and mastery, as well as regulating social and interpersonal behaviours (Lemerise \& Dodge, 2000:594).

There is no formal diagnostic category for anger. It is evaluated as an emotional condition and not a clinical condition such as anxiety and depression (Novaco \& Welsh, 1989:40).

Several theories explain behaviour. One such theory is personal construct psychology. This is a phenomenological approach which, in essence, holds that identity is defined by the way a person construes or understands their personal world. It emphasises the human capacity for attributing meaning and ongoing revision of personal systems of knowing over time (Neimeyer \& Bridges, 2004:2). A person's "constructs" or ways of making sense of the world are not necessarily conscious or articulate, but may be inferred from behaviour. Kelly (1963:105) describes a construct as "a way in which some things are construed as being alike and yet different from others". 
Cummins (2006:4) argues that in order to understand anger within personal construct psychology, it is critical to take note of six key concepts. These are anticipation, invalidation, hierarchy, hostility, permeability and sociality.

The idea of anticipation is central to personal construct psychology in that a person's processes are psychologically channelled by the ways in which they anticipate events (Kelly, 1991:32). Individuals' whole being is derived from the way they are able to construe their past, present and future. When this process is interrupted or interfered with, these individuals will not be able to satisfactorily construe the events they are confronted with. When this happens, a person may be invalidated. There are many possible responses to the inability to construe; anger is but one. When the reaction is anger, what is immediately seen is the emotional expression known as anger. It can be argued that the emotional expression can be understood as signifying change or resistance to change, and that emotions are therefore expressions of construct (Cummins, 2006:4).

Validation refers solely to the verification of a prediction, even if that prediction in itself was unpleasant. Validation affects the construct system at various levels. Constructs, which are functionally the closest to the constructs on which the original prediction was based, are the most affected by the validation experience (Kelly, 1991:111). Individuals' construct systems vary as they successively construe the replication (Kelly, 1991:50). Their understanding varies as they deal with the construct being validated or invalidated. If they never change their view on a certain aspect, for example that no one can be trusted, they will act in the same way over the years. They will never find out that some people are trustworthy. If they make an effort to find out whether people are trustworthy or not and discover that some are, they can move on. The succession of these discoveries and dislodgements constitutes the human experience (Kelly, 1991:18). The clinical problem, according to Kelly, arises when the discovery is continually invalidated, for example when the people they now trust continually let them down.

Each person's construct system is hierarchically organised. Some constructs are therefore subordinate or more central to the person. To understand and work with anger, it is also important to unpack a person's construing, which will lead to determining a person's higher-level values. Cummins (2006:7) illustrates these hierarchical levels of values with the example of a woman who gets angry because her partner leaves the toilet seat up. When Cummins starts to unpack the woman's construing, it becomes clear what is actually 
happening. The woman has told her partner that his behaviour irritates her. He does not acknowledge her irritation by changing his behaviour. Each time she comes to the toilet and finds that he has left the toilet seat up, her interpretation is that he has not listened to her and she begins to construe that he is not listening to her because he does not respect her. And if he does not respect her, he cannot love her. Loving is thus the higher-level value and superordinate to respecting and listening. Epting (1984:52) points out that the crucial aspect of love is that the "loving act" is always in a direction that is intended to complete a person. In the case of the woman and the toilet seat, her partner, by leaving the toilet seat up, was not completing her and thus not being sensitive to her needs.

A hostile person may try to force evidence to fit their anticipation,e.g. "If you do not love me, I will make you love me."

A permeable construct is one that allows for new information to be included within the construct. An impermeable construct, e.g. states "If you disrespect me, then I must physically beat you up." If it becomes permeable, then it can be accepted that you may not have meant to disrespect me and that there may be ways of responding other than immediate violence (Cummins, 2006:8).

The sociality corollary focuses on how a person relates to others. "To the extent that one person construes the construction processes of another, he may play a role in a social process involving the other person." (Kelly, 1991:66.) The critical issue here is for the person to understand how the other person sees the world. If one person must anticipate another person, they must take some chances to try and sense what the other person is up to. If a person is frequently angry and violent, the question is, "What is he or she up to?". This behaviour will cause the victim to find something beyond their overt behaviour that caused it and they might revise their behaviour accordingly (Kelly, 1970:25).

People who are admitted to a religious cult find themselves in a "new" world. This new world of the cult has dictated a new superficial personality and identity according to which they must behave, act and react. Their behaviour has changed radically and ties with family, friends and support structures outside the cult have been cut. The world outside the world of the cult is an "evil" one from which God has saved them. There is no chance of returning to this evil world; thus, all onslaughts from outside must be resisted. All accusations of being deceived and of being in a cult must be rejected and interpreted as an attempt from the devil to pull them away from 
God. The world of the cult is "pure" and the world outside "impure". Cult members must resist and stay true to the cult at all costs. They thus find themselves in emotional and in some cases also in geographical isolation as a result of the cult's subtle suggestions about the outside world. As a result of this strong belief, cult members commit whole-heartedly, giving up everything: possessions, ambitions and family.

As a result of their level of commitment and everything they have sacrificed in order to be obedient to "God's calling", cult members anticipate a closer relationship with God. The suffering they endure by living a primitive life and withstanding persecution is construed as worth the while in order to realise this sacred aim. Once cult members leave the cult, the construing process that gives sense to that lifestyle is interrupted and interfered with, leaving them with the inability to construe. They find themselves not only outside the world of the cult that dictated and kept in place certain actions, but also without the thinking and deciding agent - the cult leader. In addition, they realise, or at least strongly suspect, that they have been misled and that they have surrendered everything for something they believed to be authentic, which has turned out to be a lie. Their purpose, total lives and beings have been invalidated. Their core construct system made up of religion, family, culture and support systems has been invalidated. Important to understand is the fact that cult members are initially moved to join the group through the very same process of invalidation. Their own worlds and lives are portrayed as insufficient and the need for validation is thus created. The new cult life is presented as a correction to and validation of their lives. On leaving the cult, the same process of invalidation repeats itself. The repeated invalidation, first of the person's own world and later of the cult's world, complicates the construing. Not only was the way the cult members construed their old life and world interfered with, but now the ideal world of the cult is also invalidated. Consequently, cult members experience difficulty in construing their past, present and future.

This experience on the part of cult members impacts on the hierarchical organisation of their construct system. When members realise that they have been misled and deceived by the religious cult, they attempt to deal with this emotional and psychological disarray on their own - out of fear that nobody will understand or believe what they are going through. The cult leaders' deceiving actions and teachings that caused the members to give up everything in order to follow "God" are interpreted as disrespectful, uncaring and unloving. 
Due to the deep-seated belief established in the cult construct system, whereby the "prophet" enjoys godly sanctioning (Harrison, 1990:12), the members draw a parallel between the "prophet" and God. The "prophet" is viewed as a representative of God. The actions of the "prophet" are interpreted as unloving and uncaring. Thus God, whom the "prophet" represents, is also viewed as unloving and uncaring. Cult members' relationship with God, which they believed to be the basis of their commitment and the whole cult experience, is seriously impaired. Furthermore, the realisation that they have been deceived causes members to be distrustful and they hardly ever become involved in any religious organisation again.

Cult members' cult experience also impacts on an interpersonal hierarchical system. Members deal with the psychological disarray by interpreting it as being suffering needed to enable them to be victors in the cause of God's kingdom. Their interpersonal relationship with other members in the group is mostly that of camaraderie. The leader(s) and other senior members are on a supposedly higher spiritual level and must be followed and modelled. The modelling of leaders seems to be effective because cult members view the leader's relationship with God as a direct line of contact based on his/her status as "God's anointed". Furthermore, the attainment of a higher spiritual level is anticipated by stringent adherence to the cult prescriptions.

Leaving the cult destroys this hierarchical system and creates a sense of confusion, disorientation and powerlessness in the cult member. The emotional expression of this situation is anger. This anger is felt not only towards the deceiving leader(s), but also towards the "self" for allowing this situation to cause so much damage to personal and family life. As a result, cult members are cautious and distrustful of any person or system for fear of continued invalidation and of being let down again. To protect themselves, they develop an antagonistic attitude towards any helper or religious system. In some cases, cult members become so hostile that they want to physically harm the cult leader. To get the cult member to a place where the healing process can commence, this emotion of anger needs to be addressed.

\subsubsection{Understanding anger}

Two important elements of anger need to be understood, namely anger towards the leader and anger the members experience towards themselves. 
The anger of cult members towards the leader can be understood by adopting the following guidelines:

- Explain the subtle process that the cult utilised to entrap members.

- Explain how the particular member fell prey to this deception.

- Explain how this whole process impacts on the members' total being by shedding some light on the process and by assisting the understanding of the array of emotional and psychological experiences they will undergo.

The anger members experience towards themselves can be understood by explaining

- that involvement in the group was the result of an honest desire to serve God - the member's pure motive;

- that the decision to become a member was based on the information available at the time and that it was not a willful decision to harm themselves or others; and

- the importance of self-forgiveness in order to move forward on the road to recovery.

Once the emotion of anger is dealt with, the other emotions can be addressed.

\subsection{Fear}

Human fears are not random. Some fears are very common and others are extremely rare. Many fears are focused on objects that threaten survival, such as potential predators, unfamiliar places and the dark. These fears are provoked by tangible stimuli or situations with a high peak of intensity and are collectively known as acute fear. Chronic fear, on the other hand, refers to fear of getting old or being alone, entails a longer duration, is not necessarily connected to tangible stimuli or situations, and is harder to detect (Ben-Ze'ev, $2000: 48)$. Ben-Ze'ev (2000:479) also points out that there is consistent evidence confirming that membership of a small, cohesive group can play an important role in controlling fear. On the one hand, a fear-inducing situation is less distressing if people think of themselves as being accompanied rather than alone. On the other hand, when people are in a group, they are more vulnerable to fear by contagion. 
Extreme danger jeopardising a person's life elicits intense fear and may have long-lasting consequences in the form of post-traumatic stress disorder (PTSD) (Ohman, 2000:575). A comprehensive study on self-reported fear by Arrindell et al. (1991) found that fear can be classified into four factors. The first factor entails fear about interpersonal events and situations. These involve fear of criticism, rejection, social interaction, conflicts and evaluation, as well as interpersonal aggression and displays of sexual and aggressive scenes. The second factor involves fear of death, injuries, illness, blood and surgical procedures, contamination, syncope or other threats of physical health. The third factor includes fear of domestic animals, insects and reptiles. Finally, agoraphobic fears is the fourth factor that refers to fear of entering public places, crowds, tunnels, closed spaces, elevators, trains, buses and bridges (Ohman, 2000:575).

The classification of fear experienced by cult members is a combination of fear of interpersonal events, the fear of death and illness and, in some cases, the fear of crowds or other people.

Cults apply guilt in various ways to control their members. Firstly, they keep cult members in the behaviour pattern of the cult by instilling fear that if they do not follow instructions, they are disobeying God and will be rejected not only by the group, but also by God. Emphasising God's disappointment when the cult members do not obey Him, especially after He has called them to be part of his "chosen people", subtly implants fear. Fear of eternal rejection by God and the inability to survive in the outside world cause members to reconsider their actions. A renewed commitment to the requirements of the cult is the general result.

Another form of fear is instilled by the measures taken by cults to punish or correct straying cult members. The harshest form of punishment entails being ignored or rejected by the other members until the victim confesses. It can include doing the dirty work in the group. It also involves placing curses on members and informing them that they or their family will become sick and die if they leave the group or disobey orders. Internal spying among cult members is another way of obtaining information about straying members (Singer \& Lalich, 1995:77).

At a gathering of a group in Mpumalanga the leader warned members that if people did not believe him or accept his authority, they would fall to the ground and die when they walked into the sacred place (his church) (Anon., 1999:23). A member of another group and her family considered leaving the group after years. The leader 
warned her that if they left the group her husband would become an alcoholic and they would divorce and be ruined financially. The belief that God guides members by means of certain illnesses also instilled fear in this particular group. They were made to believe that a stomach ache was a clear indication that they were out of God's will and had to repent. They also had to pray and ask that the angel of death take away those who were disobedient (Pienaar, 2004). Miller (2003), who belonged to another group in Limpopo, was cursed when she left the group. The leader said that the wrath of God would be dealt to her and her family and that she would never be happily married.

In some groups members leaving the group are requested to make some pledge or sign a contract that they will not disclose any information to anyone. Pienaar (2004) had to sign a contract not to disclose any information about the group he belonged to. The contract also stipulated that they could be fined R100 000 should they disclose any information.

Fear is further utilised to avoid contact with those not belonging to the group. Fear of contamination by the "evil spirits" of the outside world subtly isolates members from outsiders. A sister of one of the members of a cult requested that they pray for her because she had been diagnosed with cancer. The leader gave orders not to pray for her since praying for her would bring the "cancer spirit" into the group. She was informed in writing that they could not pray for her and that she needed to change her lifestyle and diet (Pienaar, 2004).

Eventually, fear isolates members from the outside world.

\subsubsection{Characteristics of fear}

A person gripped by fear may pass through various emotional stages. A good example of these stages may be observed in a cornered rat. It will initially try to run away and escape from the enemy chasing it. If it is cornered, it will fight back with aggression until it either escapes or is captured. When humans are in a similar position, they can become very intimidated by fear, causing them to go along with another's wishes regardless of their own feelings. They can also become equally violent. Fear is the flip side of anger. It is the inbuilt human "fight or flight" response. Fear can turn into anger.

Emotions like fear can often cause extreme and seemingly irrational behaviour in people. People are essentially sociable, with shared 
values, religion, traditions, language and culture. Whenever the basic characteristics tying the group together are threatened, the group will endeavour to get rid of the threat - sometimes by distorted and violent means. Leaders need support from their followers and one way to gain their support is by playing on the followers' fears (Barker, 2003:2).

Cults have their own traditions, religion, culture, shared values, and function as a society. A strong camaraderie is formed among members, who believe that their suffering and commitment is for a sacred cause. Fear of losing this special calling and fear that the evil outside world will destroy the society or "people of God" moves them to take irrational and sometimes very radical steps. In the case of Jim Jones and the People's Temple, more than 900 members committed suicide (Jordan, 1996:119). The massacre of the Branch Davidians in Waco Texas was also related to their fear of being invaded by the worldly system (Jordan, 1996:112). Members of a group in South Africa were willing to undergo plastic surgery out of fear that their appearance would hinder them in fulfilling God's will (Pienaar, 2004).

Cult members are given the impression that there exists strong unity in the group as a result of their belief. In reality, fear is utilised to create this perception of strength and unity.

Guilt goes hand in hand with fear.

\subsection{Guilt}

Guilt stems from the commission or omission of a specific deed that has violated certain norms. The violated norms that give rise to guilt are mostly, but not always, moral (Ben-Ze'ev, 2000:498). Guilt is an affective state in which a person experiences conflict about having done something that they believe they should not have done. A number of causes of guilt have been put forward. Some evolution theorists believe that guilt is a rational human emotion selected by evolution. If a person feels guilty when they have harmed someone else and fails to receive kindness in return, they are less likely to harm others or become too selfish. Their chances of experiencing retaliation from the members of the tribe are reduced and their survival prospects increase. Others view guilt as something assigned by social processes such as trial by jury, which is a strictly legal concept. Then there are those, some of whom are theists of various types, who believe that guilt arises from violating universal principles of right and wrong. Another viewpoint of particular interest 
to this study is the view that guilt is used as a tool of social control. Since guilty people feel they are undeserving, they are less likely to assert their rights and prerogatives (Wikipedia, 2007:1).

Guilt can also be explained as covert self-punishment, which motivates ritualistic or fantastic compensatory behaviour or substitutes for this behaviour to make a person suffer (Keen, 2002:61). In religious cults guilt plays an important role. It is utilised to control people and move them to do what the cult expects of them. In one group a member who joined the group had a vehicle of his own. After a period in the group the leader started to hint at the fact that being the only member in the group to have a vehicle was selfish and that selling the vehicle or giving it to the group would serve the purpose of God better (Basson, 2003). In this particular instance guilt was utilised to move the cult member to offer his vehicle for the sake of God's kingdom. Leaders also utilise guilt to restore or reaffirm their authority. In one group, the leader accused a member of being sinful and, as a result of her sinfulness, she had to endure pain and sleep on the floor while she could sleep in a bed. This particular member felt so guilty about the consequences of her sinfulness towards "God's anointed" that she repented and recommitted to the group (Pienaar, 2004). In another group, women were subtly discouraged from wearing make-up and having long hair because it would require too much of their time and have a negative influence on their relationship with God. The women felt guilty every time they attended to their outward appearance because of the effect it could have on their relationship with God. They cut their hair and wore no make-up (Basson, 2003; Miller, 2003).

The important point to note in the context of religious cults is the fact that guilt is used both as a means to obtain required behaviour from the members and as a controlling tool. In other words, the guilt under discussion is not a self-experienced guilt, but a fabricated guilt. Thus, it could be called a false guilt aimed at controlling people.

\subsubsection{Effects of guilt}

Guilt has certain serious effects on a person. The following applications found among cult members can be added to the effects of guilt listed by Messina and Messina (2007:3):

- Over-responsibility: People with guilt feelings always strive to make life perfect and, in the process, overexert themselves. They are willing to give everything to make everyone happy. This 
particular reaction fits nicely into the cult environment and causes members to work harder and harder to live up to the standards of the group and leader. The applicable saying in cults is: "You can never do enough for God."

- Overconsciousness: Individuals anxiously fret over every action in case it may have negative consequences for others. After a while, cult members begin to believe that they can only follow and obey God via the instructions of the leader. They become passive about decision-making and "play safe", leaving it up to the leader to make decisions for them which they then obey.

- Oversensitivity: Members tend to see right or wrong in every aspect of life and become obsessed with the tenuous nature of all of their personal actions, words and decisions. They are sensitive to cues of others which might imply wrongdoing. Spying on one another is common practice in cults. Cult members are always looking over their shoulders to make sure that their actions are in line in order to avoid being reported to the leader.

- Immobilisation: The fear that what they do may be wrong overwhelms the members and, as a result, they choose to be inactive and silent, maintaining the status quo. Their fear of doing wrong and upsetting God renders them inactive in addition to emotionally and physically dependent on the cult and its prescriptions.

- Ignoring emotions: To ignore and overcome guilt, members become emotionally blocked and closed off. This reaction is a common one found among cult members. It is a way of dealing with their confusion by becoming almost emotionless and "robot-like".

- Lack of direction: Since guilt is caused by many irrational beliefs, individuals may be unable to sort out their feelings. All the information they are bombarded with - the practices of the group and the emotional and psychological transition they have undergone puts them in a position where they are unable to sort out their feelings and need professional help.

\subsubsection{The power of guilt}

Guilt is a very powerful emotion that can be utilised to control people. Messina and Messina (2007:2) indicate how this is done. One person can make another person believe that failure to respond positively to a request will bring great suffering. Cults utilise this application of guilt with great success. A cult member's reluctance to commit to the cult or to follow the leader's instructions will bring 
God's wrath down upon the whole group. The cult member's unwillingness to obey will be presented as a hindrance to God's will being manifested in the group. Once false guilt is inculcated in the cult members, it will act as a referee guiding them back to the cult prescriptions everytime they allow impermissible thoughts that question the bona fides of the group.

Accusing members of misdeeds, words or actions in order to arouse a sense of guilt is another application worth noting. The cult leader David Koresh was known to elicit guilt in this way. When some members disagreed or questioned his teaching, he would turn it around and describe it as an attempt by the enemy to pull the member away from the truth. Members' critical evaluation and rationalisation of the leader's teaching are subtly played down as enemy tactics to contaminate and destroy members. Each time members want to differ from or question the doctrine of the group, the suggestion that it is the enemy brings about guilt that will steer them away from independent thinking and back to group thinking.

Guilt is also used to reinforce negative self-perceptions. Cult members are initially made to believe that their life outside the group is bad. While in the cult, they are continuously reminded that the cult has taken them in - regardless of their bad past. This makes the members feel privileged and careful not to jeopardise this relationship. Cults employ this perception of being "special" or "privileged" as a way of making members feel guilty if they step out of line.

Cults are also adept at building verbal or imagined scenarios to show that members are at fault for inaction. This guarantees a sense of guilt and a willingness to do anything to absolve them.

\subsection{Importance of explaining guilt and fear to cult members}

In religious cults the emotions of guilt and fear are utilised to get members to submit to the authority of the leader so that he/she can gain control over them.

Unfortunately, these feelings of guilt and fear are carried over into the world to which members return after they have left the cult. To help members overcome guilt and fear, we need to explain the origin and purpose of these emotions: that both the guilt and fear are false; that they have been elicited with the purpose of manipulating members; that the threats and curses used to cause fear are unfounded; that they are acting irrationally as a result of the engendering of these emotions. 
Most of the time, members cannot believe that they have acted in the way they did. Explaining the dynamics and the power of guilt and fear and how these have affected them, will bring them to a point where the process of reintroducing them into the world can commence.

\section{Conclusion}

It is clear from the discussion that cults create a particular emotional state in the minds of their members, which acts as a referee to ensure that members keep within the boundaries of the prescriptions of the group. This emotional state ensures emotional dependence on the group and submission to the control of the cult leader. To reintroduce the recovering cult members to the world outside the cult, these emotions need to be addressed. If this is not done, the particular embedded emotional state created by the cult dynamics will prevail and cause the victims to continue living accordingly. This will, in turn, hamper any progress towards re-establishing the cult member in society.

\section{List of references}

ANON. 1999. Interview conducted with member of religious group in Mpumalanga.

ARRINDELL, W.A., PICKERSGILL, M.J., MERCKELBACH, H., ARDON, M.A. \& CORNETT, F.C. 1991. Phobic dimensions: 3. Factor analytic approach to the study of common phobic fears: an updated review of findings obtained with adult subjects. Advances in behaviour research and therapy, 13:73130.

BARKER, P. 2003. Fear. http://www.beyondondintractability.org/essay/fear? nid=1149 Date of access: 22 Nov. 2007.

BASSON, C. 2003. Personal account of ex-cult member of Alon Christian Fellowship.

BEN-ZE'EV, A. 2000. Subtlety of emotions. Cambridge: MIT.

CUMMINS, P. 2006. The construction of emotion. (In Cummins, P., ed. Working with anger: a constructivist approach. West Sussex: John Wiley. p. 1-12.)

DAMIANI, R. 2002. Spiritual abuse within the church: its damage and recovery process. Evangel, 20(2):42-48.

EPTING, F. 1984. Personal construct counselling and psychotherapy. London: Wiley.

HARRISON, S. 1990. Cults: the battle for God. London: Helm.

HENKE, D. 2006. Spiritual abuse. http://www.watchman.org/profile/abusepro. htm Date of access: 22 Nov. 2007.

JOHNSON, D. \& VANVONDEREN, J. 1991. The subtle power of spiritual abuse. Minneapolis: Bethany House.

JORDAN, M. 1996. Cults, practices, prophecies and personalities. Britain: British Library. 
KEEN, E. 2002. Depression, self-consciousness, pretending, and guilt. Westport: Praeger.

KELLY, G.A. 1963. A theory of personality. New York: Norton.

KELLY, G.A. 1970. Behaviour as an experiment. (In Bannister, D., ed. Perspectives in personal construct theory. London: Academic Press.)

KELLY, G.A. 1991. The psychology of personal constructs. London: Routledge.

LANGONE, M.D. 1993. Spiritual abuse. New York: Norton.

LEMERISE, E.A. \& DODGE, K.A. 2000. The development of anger and hostile interactions. (In Lewis, M. \& Haviland-Jones. J.M., eds. Handbook of emotions. London: Guilford. p. 594-606.)

MESSINA, J.J. \& MESSINA, C.M. 2007. Handling guilt. http://www.coping.org/ growth/guilt.htm Date of access: 22 Nov. 2007.

MILLER, K. 2003. Personal account of ex-member of Alon Christian Fellowship.

NEIMEYER, R.A. \& BRIDGES, S.K. 2004. The internet encyclopedia of personal construct psychology. http://www.pcp-net.org/encyclopedia/pctheory.html Date of access: 9 Nov. 2007.

NOVACO, R.W. \& WELSH, W.N. 1989. Anger disturbances: cognitive mediation and clinical prescriptions. (In Howell, K. \& Hollins, C., eds. Clinical approaches to violence. Chichester: Wiley. p. 36-60.)

OHMAN, A. 2000. Fear and anxiety: evolutionary, cognitive, clinical perspectives. (In Lewis, M. \& Haviland-Jones, J.M., eds. Handbook of emotions. London: Guilford. p. 573-593.)

PIENAAR, E. 2004. Personal account of ex-member of the group known as The Way.

SINGER, M.T. \& LALICH, J. 1995. Cults in our midst. San Francisco: JosseyBass.

SNOW, D.A. \& MACHALEK, R. 1984. The sociology of conversion. Annual review of sociology, 10:167-90.

WIKIPEDIA. 2007. Fear. http://en.wikipedia.org/wiki/fear Date of access: 22 Nov. 2007.

ZUKERAN, P. 2006. Abusive churches. http://www.caic.org.a/biblebase/abuse/ abuse-ch.htm Date of access: 31 Jul. 2006.

\section{Key concepts:}

\section{anger}

fear

guilt

religious cults

\section{Kernbegrippe:}

godsdienstige kultes

skuldgevoel

vrees

woede 